\title{
PEDRO CLAVER Y LA LABOR DE EVANGELIZACIÓN EN CARTAGENA DE INDIAS (SIGLO XVII). FUENTES CLAVES PARA ANALIZAR A LOS AFRICANOS EN EL NUEVO MUNDO'
}

\author{
Paola Vargas Arana \\ Mestre del Centro de Estudios Asiáticos y Africanos de El Colegio de México \\ Professora de Historia de Africa, Faculdade de Ciencia e Tecnologia EaD (Salvador- Ba)
}

\begin{abstract}
Resumo
El artículo analiza el documento de canonización de Pedro Claver referido a su trabajo de evangelización de africanos en Cartagena de Indias durante el siglo XVII. El objetivo es cuestionar la labor y la utilidad del santo en la formación identitaria del puerto. En particular propone que el santo intentó hacer del cristianismo uno de los pilares de esa identidad, al punto de generar alianzas entre los sectores europeos que se hallaban en pugna por el control político y económico del puerto. Sin embargo, fracasó en la empresa de extirpar las herencias africanas recreadas como respuesta a las tentativas de evangelización de Claver.
\end{abstract}

\section{Pallavras-Chave}

Cartagena de Indias • Africanos y Jesuitas siglo XVII • Evangelización de Africanos

\section{Abstract}

The article analyzes the Pedro Claver canonization process which shows his work of evangelizing African people in Cartagena de Indias during the XVIIth Century. The main objective is to question the saint's utility in the identity formation in the port. The article proposes the saint tries to make the Christian religion one of the aspects of that identity; secondly, he helped to generate alliances between European factions that were looking toward the economic and political control of the port. Nevertheless, he failure in his intention to eradicate the African heritance, which continue in Cartagena's cultural diversity.

\section{Keywords}

Cartagena de Indias XVIIth Century • Africans cultural expressions • Jesuits' evangelization

\footnotetext{
${ }^{1}$ La investigación fue auspiciada por el premio Ayudas a la Investigación en Historia Colonial otorgado por el Instituto colombiano de Antropología e Historia en el año 2004. Antes de comenzar quiero agradecer a los profesores Gianni Criveller y Elisabetta Corsi por el seminario
} 


\section{Introducción}

La historiografía colombiana reciente ha realizado múltiples reflexiones sobre las formas de contacto establecidas entre nativos americanos y europeos durante el periodo del "descubrimiento" y colonización de América. Pocos, sin embargo, consideran la participación cultural de los africanos que llegaron al continente. Tan solo se toma en cuenta su papel en la economía esclavista y en los servicios prestados a la sociedad colonial. Dejar fuera de este proceso los aportes culturales de una población diversa y numerosa en la formación de las sociedades latinoamericanas, impide comprender tanto la complejidad social que presentaban las colonias como las identidades nacionales, étnicas y religiosas del presente.

El que las poblaciones africanas y sus descendientes no poseyeran escritura se ha utilizado como argumento principal para mantener este gran sector de la población excluido de los estudios culturales de la historiografía colonial. En la actualidad, sin embargo, se ha hallado documentación que prueba la llegada de elites islamizadas a Brasil, Jamaica y Estados Unidos quienes produjeron por si mismos extensa documentación en árabe e inclusive en inglés ${ }^{2}$.

No obstante, las elites islámicas llegaron en menor medida a otras regiones del "Nuevo Mundo". Esto dependió en gran medida del periodo en el cual se produce la llegada de personas desde África y los lugares de proveniencia de los africanos. Este es el caso de Cartagena de Indias, puerto principal de la provincia hispánica del Nuevo Reino de Granada, donde la entrada de población esclavizada es muy temprana y perteneciente, en su mayoría, a culturas ágrafas.

La ausencia de escritura no significa que la participación de los africanos y sus descendientes en las culturas de coloniales del Nuevo Mundo sea

\footnotetext{
"Ex Oriente Lux. La expansión del Cristianismo en Asia del Renacimiento a la Ilustración" impartido durante la maestría de Asia y África en el Colegio de México, donde discutimos con gran dedicación el nacimiento y la labor de la Compañía de Jesús. A mi maestra de historia de Âfrica Celma Agüero, por darme luz con respecto a la perspectiva africanista. A los profesores Jaime Arocha y Pablo Rodríguez por su constante apoyo en la primera etapa de escritura. También agradecer la corrección de la versión final al profesor Carlos Zerón y demás miembros de la línea de investigación "Escravidão e História Atlántica" de la Universidade de Sao Paulo quienes leyeron el texto con dedicación e hicieron interesantes sugerencias acerca del papel de Claver y la especificidad de los africanos en el puerto de Cartagena.

${ }^{2}$ Acerca del tema ver LOVEJOY, Paul (ed.). Slavery on the frontiers of Islam. Princeton, Marcus Weiner Publishers, 2004.
} 
inexistente. La siguiente investigación apoya a Martin Lienhard ${ }^{3}$ quien afirma que es posible encontrar la voz de quienes no participaron en la escritura de los documentos cuando se conoce profundamente el contexto sociopolítico y los roles que cada sujeto desempeñaba. Así, la intención es interpretar las fuentes escritas por europeos, para conocer la participación de las poblaciones africanas durante la primera mitad del siglo XVII en Cartagena de Indias. En segundo lugar, la investigación busca entender la manera como los europeos y sus descendientes imaginaron y trataron a los africanos en ese puerto.

La fuente eclesiástica que se utiliza en este trabajo fue escrita en la segunda mitad del siglo XVII y es denominada Proceso de Canonización y Beatificación de San Pedro Claver. El documento tuvo el objetivo de convertir a este jesuita denominado esclavo de esclavos, en un santo católico. De ahí que la narración este dirigida a resaltar las virtudes cristianas de esa persona. A pesar de esto, el texto es interesante para la historiografía porque revela aspectos de la vida social del puerto, el tipo de vínculos entre los diferentes sectores de la sociedad, incluyendo los sectores africanos, y la ideología de quienes buscaron hacer de Claver un santo.

Por otra parte, consideramos aquí los límites de este tipo de fuente. Dado el carácter eclesiástico y el objetivo de elevar las virtudes de Claver, el documento no puede dar cuenta de procesos sociales. Sin embargo, adherimos a la tesis de Michel de Certeau quien observa que registros de esta clase, abren la posibilidad para observar aspectos ideológicos de las sociedades que dificilmente se puede observar en otras fuentes.

Otro motivo para trabajar el Proceso deriva del escaso volumen de fuentes estudiadas sobre el puerto, dada la desaparición del archivo de Cartagena correspondiente a los siglos XVI y XVII. El problema fundamental está en el acceso a los documentos cuyas copias yacen en el Archivo General de Indias en Sevilla (España). Tampoco se ha hallado la correspondencia escrita por Pedro Claver. Hasta el momento se recuperó una carta referida a su predilección por los negros. La carta fue encontrada por el jesuita Angel Valtierra, reconocido biógrafo del santo. Todo lo anterior hace del siguiente artículo una semilla que impulsa a nuevas investigaciones sobre la vida social de los africanos y sus descendientes en la colonia neogranadina.

${ }^{3}$ LIENHARD Martin, "Una tierra sin amos. Lectura de los testimonios legales de algunos esclavos fugitivos (Puerto Rico y Brasil, Siglo XIX)”, en América Indígena 54, no. 4 (1994), p. 210. 
Aquí analizamos la labor evangelizadora de Pedro Claver la cual, según narran los testigos, le mereció la admiración de los diferentes sectores sociales de Cartagena. Su forma de evangelizar revela dos caras específicas, una referida a la realización de acciones caritativas nacidas de su preocupación por comprender una población que la sociedad cartagenera ni siquiera consideraba humana. Esta cara de la labor claverina presenta relación con las misiones llevadas a cabo por la Compañía de Jesús, las cuales fueron dirigidas a acomodar el cristianismo a las distintas sociedades que "encontraron" en el llamado "periodo de los descubrimientos".

Una segunda cara revela el método evangelizador de Claver como cardinal para impedir el ingreso de los africanos a la cultura letrada en el puerto. Al tiempo que el jesuita intentaba comprender las culturas de los africanos, castigaba sus expresiones con dureza y servía como testigo para su condenación ante el Santo Oficio de la Inquisición. En ese sentido, el objetivo último seguía siendo extirpar las prácticas africanas que consideraba demoníacas y supersticiosas.

Desde la perspectiva africanista, las descripciones de dichas prácticas, los nombres y los detalles de las historias personales de los africanos, permiten generar finas hipótesis acerca de las sociedades y sujetos africanos que estaban llegando a Cartagena. Los 154 testigos hacen referencia a 483 habitantes de los cuales 94 eran esclavos (de un total de habitantes calculado en 5000 para comienzos del siglo XVII ${ }^{4}$ ). Clasificamos los nombres de esos esclavos en la Tabla 1 y concluimos que en ese periodo estaban llegando al puerto personas provenientes de la región occidental de África Central y de la costa de África Occidental desde la actual Nigeria, hasta Senegal. El occidente de África Central incluye los actuales estados de Camerún, Gabón, Congo, la República Democrática del Congo y Angola. La amplitud de ambas regiones permite inferir la gran diversidad cultural representada en el puerto de Cartagena para el siglo XVII. En ese sentido, no basta con decir que eran africanos, al contrario se trata de asociar las expresiones rituales o simbólicas a determinadas culturas para entender cuales eran los mecanismos para mantener o reedificar estas expresiones en América.

En el último aparte se formula una tesis sobre la funcionalidad de Claver como santo. Esta figura fue un pilar identitario dentro del proyecto de creación

\footnotetext{
${ }^{4}$ MEISEL ROCA, Adolfo, AGUILERA DÍAZ, María, "Cartagena de Indias en 1777: un análisis demográfico" en Boletín Cultural y Bibliográfico, Vol. 34, num. 45, 1997.
} 
de una única sociedad cartagenera, pues logró unir a españoles y portugueses bajo el objetivo común de adoctrinar a los africanos. En ese sentido, Claver no sirvió a los africanos como plantean algunos, tampoco fue útil para legitimar la esclavitud como plantean otros; Claver estableció objetivos en común entre los sectores europeos rivales en el puerto.

\section{Historiografía claverina}

El jesuita Pedro Claver ha sido objeto de multiples apologías a lo largo de los siglos. Existen biografías, historias fantásticas sobre milagros y tratados antiracistas cuyo protagonista es el catalán dedicado a la evangelización y atención de los bozales - personas llegadas directamente del continente africanoa Cartagena de Indias. La mayoría de estas narraciones usa como fuente el voluminoso Proceso de Beatificación y Canonización ${ }^{5}$ escrito por los testigos que convivieron con el jesuita entre 1620 y 1654, época en la cual vivió en el puerto. No es hasta el año 2000 que la historiadora Anna María Esplendiani, colaboradora del padre Tulio Aristizabal S.J. en la traducción y transcripción del documento, se aventura a proponer una interpretación secular de Pedro Claver. Ella argumenta que el sector "blanco" de Cartagena elaboró el santo para legitimar el trato hacia la población africana esclavizada. ${ }^{6}$ Además Splendianni describe un puerto en plena edificación arquitectónica y construcción identitaria que requería un santo para consolidarse plenamente.

\section{El Proceso}

El documento Proceso de Canonización y Beatificación de San Pedro Claver compendia la literatura escrita durante el proceso eclesiástico que dio el titulo de santo a Claver. La historia de su redacción empieza el año de su deceso 1654, cuando el gobernador de Cartagena Pedro Zapata de Mendoza y el Consejo de la ciudad solicitan al Capítulo de la Catedral iniciar una pesquisa

\footnotetext{
${ }^{5}$ ARISTIZABAL Tulio S.J. SPLENDIANI Anna María, Proceso de beatificación y canonización de san Pedro Claver. Bogotá, CEJA, 2002, p. 593.

${ }^{6}$ SPLENDIANI Anna María. Un jesuita y una ciudad: Pedro Claver y Cartagena de Indias. Tomo I. Informe final presentado a COLCIENCIAS. Proyecto No. 946, Bogotá, Mayo de 2000 (Sin publicar), p. 28.
} 
sobre la vida del jesuita. Tres años después se constituye una comisión eclesiástica para adelantar los primeros interrogatorios legales del caso. De acuerdo con los canones tridentinos, la comisión estaba precidida, por el calificador del Santo Oficio de la Inquisición Fray Juan Guerrero. Dicha comisión se encargó de llamar a las personas que convivieron con Claver, para testificar bajo juramento ante un juez del Tribunal del Santo Oficio. Ese material sirve de insumo para editar y redactar el informe que en 1696 fue enviado y presentado ante la Sagrada Congregación de Ritos en Roma. La instancia se encargó de traducir al latín e italiano y luego conducir el Proceso. En total se mantuvieron los informes de 154 testigos que fueron reagrupados de acuerdo a los items requeridos por la Iglesia. En 1773 dada la supresión de la Orden jesuita, el Proceso queda detenido hasta 1830 cuando Pio VII restaura la Orden. En 1850, Pio IX declara beato a Claver y en 1888 León XIII lo hace santo. ${ }^{7}$

La conducción del Proceso y la escritura del documento siguieron la estricta legislación establecida en la segunda mitad del siglo XVI por el Concilio de Trento. A grandes rasgos, ese Concilio se encargó de centralizar los poderes de la Iglesia en el Vaticano, imponer reglas para el funcionamiento de la institución, delimitar los poderes del clero e precisar normas sobre la devoción católica. ${ }^{8}$ Mas adelante analizaré las implicaciones de esos cambios, ahora interesa entender cómo se modeló la devoción hacia los santos. Para este fin se funda la Sagrada Congregación de Ritos, instancia encargada de conducir los procesos de canonización. Al poco tiempo el Papa Urbano VIII (1623-1644) publica la Bula "In Eminenti"donde expone los decretos necesarios para decidir cualquier santificación. Desde ahí queda reservado para el pontífice el derecho de declarar a ciertos difuntos como dignos de culto, es decir, beatos. En 1625, el mismo Papa promulgó la constitución "Sanctissimus" donde expuso el procedimiento que debía seguirse para nombrar santos, siendo esta la única instancia superior a la de beato. ${ }^{9}$

La estructura el documento presentado al Vaticano en 1696 para iniciar la canonización de Claver esta ceñido a esas normas. Una primera parte Información, sintetiza las principales virtudes cristianas señaladas por los testigos;

\footnotetext{
${ }^{7}$ ARISTIZABAL, "Proceso de beatificación", p. XVIII.

${ }^{8}$ MULLET, Michael A. The Catholic Reformation, London, Routledge, 1999, p. 30 - 68.

${ }^{9}$ ARISTIZABAL, "Proceso de beatificación", p. XIX-XX.
} 
la segunda Sumario, es el conjunto completo de testimonios agrupados en 70 numerales, luego vienen las Objeciones, donde el Promotor de la Fe presenta los reparos y la cuarta parte, Respuestas, donde el defensor de la causa responde afirmativamente a la conducción de un Proceso a Pedro Claver.

Así, el Proceso resulta un compendio de relatos sobre los milagros, los episodios heroicos y los hechos sobrenaturales protagonizados por el jesuita Pedro Claver que buscan legitimar la devoción hacia una persona. De acuerdo con esto, es inútil perseguir "lo real" o los "hechos históricos" en esta fuente. Esto no quiere decir que el Proceso carezca de material interesante para la historiografía pero sí exige una metodología de análisis adecuada al tipo de información contenida.

Según Michel de Certeau los hombres forjados como prototipos ejemplares "se sitúan en una intersección entre la evolución de la comunidad particular donde se elaboran (aspecto diacrónico) y la coyuntura sociocultural que esta evolución atravieza (aspecto sincrónico)". ${ }^{10}$ De esta manera, las producciones narrativas sobre santos, como en el caso del Proceso de Claver, son campos privilegiados para observar cuadros instantáneos de las sociedades pues "la vida de un santo se inscribe dentro de la vida misma del grupo, Iglesia o comunidad; supone a un grupo ya existente, pero representa la conciencia que este tiene de sí misma al asociar una figura a un lugar". ${ }^{11}$ Un personaje ejemplar es el modelo de persona que todos los sujetos de un colectivo buscan alcanzar, así contribuyen a consolidar la conciencia social en el sentido de asociar un espacio - aquel donde el santo vivió - y un determinado grupo social.

Así las cosas el Proceso es una fuente privilegiada para preguntar por la composición e ideología de los sectores sociales que postularon a Claver como modelo de persona. Es decir, no en cualquier sociedad aparece y se valora un personaje cuyo apelativo es "esclavo de los esclavos", caracterizado por lamer llagas a los africanos moribundos o entrar sin pudor a fosas de embarcaciones repletas de seres humanos encerrados por tres meses. Este documento es útil para rastrear el tipo de sociedad que acoge un sujeto con esas características y con qué finalidad. Para generar una interpretación de ese "instante en la formación social" fue indispensable asociar los relatos contenidos en el Proceso con la

\footnotetext{
${ }^{10}$ DE CERTEAU, Michel, La escritura de la historia, México, Universidad Iberoamericana, 1993, p. 265.

${ }^{11}$ DE CERTEAU, “La escritura de la historia”, 1993, p. 260.
} 
historiografía que se ha elaborado sobre el puerto. En especial tuvimos en cuenta las obras de María Cristina Navarrete, Enriqueta Vila Vilar, Luz Adriana Maya Restrepo, Carmen Bernard y Antonio Vidal Ortega. También corroboramos la información con documentos judiciales del periodo. En particular apelamos a dos fuentes; el proceso jurídico contra los cimarrones del palenque del Limón (1633-1644). ${ }^{12}$ Este texto es importante pues Pedro Claver bautizó y confesó a los reos antes de ser ahorcados. También se tuvo en cuenta la obra de Alonso de Sandoval, S.J. Naturaleza, policia sagrada i profana: costumbres $i$ ritos, disciplina $i$ catechismo evangelico de todos etiopes, quien dedicó su vida a describir las culturas de los africanos llegados a Cartagena en la segunda mitad del siglo XVI y comienzos del XVI, además de ser superior del Colegio Jesuita y maestro de Claver. ${ }^{13}$

\section{Pedro Claver el Jesuita Catalán}

Pedro Claver nació el 26 de Junio de 1580 en Verdu, un pequeño poblado de Cataluña al norte de la Península Ibérica y allí vivió hasta los 16 años. Recibió la mejor educación pues su familia formaba parte de la aristocracia campesina del pueblo. A los 15 años obtuvo del Obispo de Vich la primera preparación para iniciar una vida eclesiástica y fue enviado a Barcelona como estudiante externo donde realizó tres cursos de gramática y retórica. En 1601 ingresó en el Colegio jesuita de Belén en Cataluña y en 1602 entró en el noviciado de Tarragona. Luego de completada esa instrucción pasó un año en Gerona donde realizó estudios de latín, griego y oratoria. ${ }^{14}$

Claver creció en un período de importantes transformaciones en la Iglesia Católica. Desde mediados del siglo XVI se venia realizando el Concilio de

\footnotetext{
${ }^{12}$ Testimonio de los proçessos y castigos - que se hiçieron - por el Maestro de Campo Françisco de Murga gobernador y cappitan general de Cartagena - contra los negros çimarrones y alçados - de los palenques — del Limon - Polin y Çanagurae, 1633 - 1644, Patronato 234, R. 7, No. 2, Archivo General de Indias, Sevilla, 550 - 551. Dada la imposibilidad de viajar al Archivo de las Indias, se accedió a los apartes traducidos al ingles en McKNIGHT Kathryn Joy, "Confronted rituals: Spanish colonial and Angolan 'Maroon' executions in Cartagena de Indias (1634)", Journal of Colonialism and Colonial History, 5, No. 3, 2004.

${ }^{13}$ SANDOVAL, Alonso. Naturaleza, policia sagrada i profana : costumbres $i$ ritos, disciplina i catechismo evangelico de todos etiopes, Sevilla, Por Francisco de Lira impresor, 1627.

${ }^{14}$ ARISTIZABAL, "Proceso de beatificación", p. 49 -51.
} 
Trento que, fruto de un proceso ideológico, social y político de al menos tres siglos, buscó aclarar la jurisdicción de la Iglesia con respecto al campo de acción política de los reinos europeos. Esto para evitar las tensas relaciones mantenidas por esas instituciones durante la Edad Media. ${ }^{15}$ No menos importante, fue la delimitación de las variaciones regionales de las devociones populares que escapaban del control de esta institución y estaban siendo aprovechadas económicamente por el clero. ${ }^{16}$ Por ultimo, el arribo de los europeos a América, China, India y África había significado el "encuentro" con poblaciones localizadas fuera de los patrones con los cuales se pensaba a los no cristianos. ${ }^{17}$ Esta serie de problemáticas impulsaron contradicciones y reflexiones dentro del Concilio sobre la manera legítima de enseñar el Evangelio. Finalmente, Trento determinó la forma de comprender la naturaleza de las poblaciones no cristianizadas e impulsó a las órdenes a la misión de evangelizar todo el mundo conocido y por conocer.

De hecho, la fundación de la Compañía de Jesús en 1540 se enmarcó en ese proyecto. La Orden ideada por el español Ignacio de Loyola respondía a la necesidad de innovar métodos apostólicos. Tan solo veinte años después de su establecimiento la labor de dicha Orden era tan amplia y eficaz que se convirtió en elemento fundamental para las determinaciones eclesiásticas del Concilio. ${ }^{18}$ La base de la Compañía era formar discípulos que cumplieran un doble objetivo, servir a la evangelización de poblaciones no conversas y perfeccionar la devoción cristiana dentro de Europa. ${ }^{19}$

Ese proceso comenzaría tan solo 60 años antes del nacimiento de Pedro Claver. Entonces no sorprende que desde los primeros años de su vida el barcelonés estuviera influido por la fuerza ideológica y pedagógica de la Orden. Una vez terminados los estudios en el Noviciado de Tarragona, sale de Cataluña

\footnotetext{
${ }^{15}$ MULLET, "The Catholic Reformation”, 1999, p. 1 - 28.

${ }^{16}$ MULLET, “The Catholic Reformation”, p. 65.

${ }^{17}$ CRIVELLER Gianni, Preaching Christ in late Ming China, The Jesuits' presentation of Christ from Matteo Ricci to Giulio Aleni, Taipei, Ricci Institute for Chinese Studies, Variétés Sinologiques, New Series 86, 1997, p. 21 - 33. SULLIVAN, Francis, S.J. Hay salvación fuera de la Iglesia? Rastreando la historia de la respuesta católica, Bilbao, 1999, Desclée de Brouwer, p. 79 -100.

${ }^{18}$ LOYOLA, San Ignacio, Obras, en colección Biblioteca de Autores Cristianos, Número 86, Madrid, 1991, p. $437-438$.

${ }^{19}$ O’MALLEY, John W. The First Jesuits, Cambridge, Harvard University Press, USA, 1993, p. 70.
} 
para unirse a los Jesuitas en el Colegio de Montesion, Mallorca, donde realizó estudios eclesiásticos. Allí mantuvo una estrecha relación con el presbítero Alonso Rodríguez, portero del convento, quien gana el título de santo por suscitar en los jóvenes la vocación de evangelizar en las "Indias". ${ }^{20}$

Dado el espíritu de la Compañía, además de los tres votos pactados por las órdenes mendicantes: obediencia, pobreza y castidad, fue establecido que los jesuitas de mayor rango juraran cumplir un cuarto voto en el cual delegaban al Papa el señalamiento del lugar y la misión que debían cumplir. ${ }^{21}$ La imperativa necesidad del Vaticano de controlar las misiones fue otro de los motivos para que la Orden cobrara importancia de inmediato.

Para Loyola, estos jesuitas de cuarto voto debían ser elites educadas en la vanguardia académica del periodo, es decir, dentro del humanismo renacentista. ${ }^{22}$ Esta elite no debía ser receptor pasivo de esa vanguardia; al contrario debía participar en el diseño de propuestas pedagógicas que combinaran la enseñanza teológica y la ciencia. Pedro Claver fue parte del selecto grupo de aristócratas españoles educados en esos Colegios. En 1610, después de recibir la educación básica, Claver viajó a la Nueva Granada con el doble fin de terminar sus estudios de teología y artes en los Colegios de Santa Fe y Tunja. Allí se ordenó como jesuita. Después viajó a Cartagena donde, en 1622, realizó el cuarto voto jurando dedicar su vida a la conversión de los africanos del puerto. ${ }^{23}$

\footnotetext{
${ }^{20}$ ARISTIZABAL, "Proceso de beatificación", p. 6.

${ }^{21}$ O’MALLEY, “The First Jesuits”, p. 6 y 32.

${ }^{22}$ O'MALLEY, “The First Jesuits”, p. 208 - 216. FELDHAY, Rivka, “The Jesuits: An alternative intellectual elite", Cap. 6 en Galileo and the Church, Political inquisition or critical dialoge? Cambridge, Cambridge University Press, 1999, p 110 - 124. Mas que un movimiento, el humanismo fue el "espíritu" del periodo Renacentista. Al interior de la Iglesia, consistió en recuperar los escritos de clásicos griegos, principalmente Aristóteles y Platón, siempre en diálogo con una reflexión sobre la dimensión humana de Cristo. Esta tendencia tuvo el propósito de elaborar una nueva comprensión de la vida, centrada en la persona humana. La nueva ontología derivaba de aquella elaborada por los griegos, quienes dedicaron largas disquisiciones a entender los sentidos, los pensamientos, el espíritu humano y sus posibilidades. La difusión de estos pensamientos en las sociedades europeas condujo al desarrollo de las artes, la ciencia, la política y la economía.
}

${ }^{23}$ ARISTIZABAL, "Proceso de beatificación", p. 84. 


\section{Contexto social de Cartagena a la llegada de Claver}

Pedro Claver llega en el momento más álgido del tráfico de personas africanas por Cartagena. En 1580, año que coincide con el nacimiento del santo, Felipe II rey de España firmó el Acuerdo de la Dos Coronas por el cual España absorbía el reino de Portugal. Este modificó profundamente el negocio de venta de personas esclavizadas pues, desde el Tratado de Tordecillas en 1493, ningún español podía desembarcar en las costas africanas; mientras ningún portugués podía residir legalmente en las colonias americanas. El periodo de unión de las dos coronas generó inestabilidad en esas políticas al punto de crear una porosidad normativa que facilitó tanto el establecimiento de comerciantes portugueses, como la introducción de africanos al puerto de Cartagena. ${ }^{24}$

Así, a comienzos del siglo XVII Cartagena presentaba una composición demográfica de enorme diversidad cultural, lingüística y religiosa. La mayoría eran personas originarias de la región centro-occidental y occidental de África y hablaban al menos 20 lenguas (ver Tabla 1). ${ }^{25}$ Según la investigación de Meisel Roca, en el puerto había población nativa americana aunque en el Proceso solo se nombre un nativo que ni siquiera sirvió de testigo. ${ }^{26}$ Además de africanos e indígenas existía un grupo denominado "criollos" y otro de esclavos con apellidos europeos. Posiblemente ambos grupos eran descendientes de africanos, o hijos de europeos y africanos ya nacidos en el Nuevo Mundo. Por último había una minoría europea compuesta por los españoles en los cargos gubernamentales de la Corona, las haciendas y los cargos clericales, y otros europeos que, tal como aparece en la composición demográfica de los testigos del Proceso, eran portugueses judaizantes

\footnotetext{
${ }^{24}$ VILA VILAR Enriqueta, Aspectos sociales en América colonial. De extranjeros, contrabando y esclavos, Bogotá, Instituto Caro y Cuervo, Universidad Jorge Tadeo Lozano, 2001, p. 1 - 40.

${ }^{25}$ Los últimos estudios con respecto a la distribución de las culturas africanas en Colombia son AROCHA Jaime, Los ombligados de Ananse, Centro de Estudios Sociales, Universidad Nacional de Colombia, 2003, FRIEDEMANN, Nina S. De, Ma Ngombe, Guerreros y ganaderos en Palenque, Bogotá, Carlos Valencia Editores, 1987. AROCHA Jaime y FRIEDEMANN, Nina S. De, De sol a Sol, Génesis y transformación y presencia de los negros en Colombia, Bogotá, Editorial Planeta, 1986. MAYA RESTREPO, Luz Adriana. "Demografía histórica de la trata por Cartagena de Indias, 1533-1580" en Geografía Humana de Colombia. Los Afrocolombianos, 1988. DEL CASTILLO MATHIEU, Nicolás, La llave de las Indias, Bogotá, Ediciones El Tiempo, 1981 DEL CASTILLO MATHIEU, Nicolás. Esclavos negros en Cartagena y sus aportes léxicos. Bogotá, Instituto Caro y Cuervo, tomo LXII, 1982.

${ }^{26}$ MEISEL, “Cartagena de Indias en 1777”, p.30.
} 
- recién convertidos al catolicismo -, "herejes" flamencos, italianos e ingleses pertenecientes a las sectas protestantes del norte de Europa. ${ }^{27}$

Esa sociedad se encontraba en medio de un dificultoso proceso de consolidación identitaria no solo por la diversidad que la caracterizaba, sino por la movilidad de sus residentes. Los médicos, misioneros y comerciantes europeos eran personajes itinerantes que pasaban solo unos meses en la ciudad. En cuanto a los africanos, muchos eran vendidos a las haciendas continentales y rápidamente eran trasladados a su nueva morada.

En medio esta fluctuación demográfica y dada su ubicación geográfica, Cartagena ganaba una prosperidad económica inusitada. En el puerto convergían los metales provenientes del interior de la Nueva Granada, Nombre de Dios en la Provincia de Panamá y Potosí en la Provincia de Perú, para después ser conducidos a los mercados europeos. La confluencia metalífera atrajo a los grandes tratantes de esclavos que buscaban el menor número de intermediarios para canjear personas africanas por metal. Dada su eficacia como puerto y almacén de personas esclavizadas, a finales del siglo XVI Cartagena fue designada único puerto legal de la Corona Española para recibir africanos a América. Desde 1615 el puerto compartió ese status con Veracruz en la Nueva España. ${ }^{28}$

Aunque el número de africanos llegados a América aun se debate, los estudios sobre el mundo atlántico ya establecieron los lapsos de alzas y declives, así como las regiones de proveniencia en cada período del tráfico Trans-Atlántico. En particular, a mediados del siglo XVI eran traídos africanos para sustituir la mano de obra indígena desde los Ríos de Guinée, como llamaron lo traficantes al extremo occidental del continente africano (actuales repúblicas de Senegal y Guinea Bissau); de la región llamada por los europeos Costa de Mina, compreendida entre la desembocadura del Río Niger (actual Nigeria) y el Río Volta; y de África Centro-Occidental especialmente del puerto de Luanda. Esto dado que los nativos americanos que servían en la minería comenzaban a morir masivamente. En 1545 el Virrey Toledo advirtió la catástrofe que ocurriría en la Provincia del Perú de continuar los abusos en la explotación de

\footnotetext{
${ }^{27}$ ARISTIZABAL, "Proceso de beatificación", Índice de personas, p. 571. También estudiado en VILA, "Aspectos sociales", p. 1. En contados casos los funcionarios de la Corona podían ser portugueses pero la obtención del cargo derivaba de la compra de títulos.

${ }^{28}$ VIDAL ORTEGA, Antonino, Cartagena de Indias y la región histórica del Caribe, 1580 - 1640, Sevilla, Universidad de Sevilla, 2002. NAVARRETE Maria Cristina, Historia social del negro en la colonia, Cartagena, Siglo XVII, Cali, Universidad del Valle, 1995.
} 
los nativos e inclusive propuso reformas en el régimen laboral. ${ }^{29}$ Sin embargo, la Corona española hizo caso omiso a las advertencias y, para finales de siglo XVI, la catástrofe demográfica era un hecho.

Por su parte, las expediciones de europeos al interior del continente mostraban que los yacimientos de oro y plata eran abundantes. Tan solo en Remedios, Zaragoza y Cáceres, en la región antioqueña de la Nueva Granada se localizaron grandes concentraciones de oro. ${ }^{30}$ Esos hallazgos impulsaron normas que legislaron la explotación de minerales, entre ellas la imperativa necesidad de introducir africanos que suplantaran a los escasos nativos. Otras normas legislaban los precios y las cantidades de oro que cada colono podía extraer e importar. Esta normatividad nunca se cumplió a cabalidad pues el auge del mercado aurífero hizo de Cartagena uno de los sitios más apetecidos por piratas ingleses y franceses que saquearon el puerto en 1580 (Francis Drake) y 1697 (L. Pointis). ${ }^{31}$ Para completar, los mercaderes eludían impuestos y compraban títulos para poder habitar de manera permanente en la Nueva Granada.

Evadir la norma que impedía a los portugueses vivir en la Nueva Granada les permitió mantener un negocio redondo pues eran a la vez dueños de las minas y de los africanos que introducían sin intermediarios. No contentos con esa posibilidad, infiltraban africanos ilegales a todo lo largo de la costa americana. Basta imaginar que los mismos contrabandistas utilizaban los africanos en sus minas para dimensionar la opulencia alcanzada. ${ }^{32}$ Vila Vilar y Navarrete muestran que el enriquecimiento y el poder particular de la familia Gramajo, de origen portugués, llegó al punto de adueñarse de más de la mitad de los negocios, construcciones y haciendas en Cartagena. ${ }^{33} \mathrm{~A}$ comienzos del XVII también se registran casos de flamencos e ingleses que incursionaban en el negocio. La insistente creación de legislaciones que impidieran la residencia

\footnotetext{
${ }^{29}$ GONZÁLEZ CASASNOVAS, Ignacio, Las dudas de la corona: la política de repartimientos para la minería de Potosí, 1680-1732, Madrid, Consejo Superior de Investigaciones Científicas, 2000.

${ }^{30}$ NAVARRETE, "Historia social del negro", p. 21.

${ }^{31}$ SEGOVIA SALAS, Rodolfo, Las fortificaciones de Cartagena de Indias: estrategia e historia, Bogotá, Carlos Valencia Editores, 1982

${ }^{32}$ Para investigaciones específicas sobre estos personajes ver VIDAL ORTEGA, Antonino, "Jorge Fernández Gramajo, un modelo de poderoso comerciante de esclavos. La versatilidad familiar del negrero" In VIDAL, "Cartagena de Indias", p. 135 - 145. VILA, "Aspectos sociales”, p. 21 - 30. NAVARRETE, “Aspectos sociales del negro”, p. 45.

${ }^{33}$ VILA, "Aspectos sociales", p. 21.
} 
de "extranjeros" 34 y la imposición de altísimos impuestos para el ingreso de africanos, muestran el temor que ese fenómeno suscitó a la Corona. Esto también fastidiaba a las familias españolas que invertían en la minería al punto de dividir los intereses de los sectores europeos en el puerto.

El miedo quedó plasmado en el establecimiento de una infraestructura institucional y arquitectónica para fortalecer el control del puerto y conducir los delincuentes a la justicia. A comienzos del siglo XVII comenzó la construcción de la muralla y la organización del ejército. También se abrió el Canal del Dique para comunicar al puerto, a través del río Magdalena, con el interior de la Nueva Granada. En 1610 se estableció el Tribunal del Santo Oficio de la Inquisición junto con varias órdenes de caballería y cofradías para velar por la catolicidad, al tiempo que se construyeron hospitales y conventos. Es de resaltar que la mayoría de esas construcciones fueron elevadas por la población africana y afrodescendiente.

\section{Análisis del Proceso}

Según los testimonios del Proceso, desde 1615, año de su llegada, Claver ganó popularidad y reconocimiento por parte de todas estas nuevas instituciones. Participó de la vida conventual del Colegio de la Compañía fundado 25 años antes de su llegada; fue enfermero en los hospitales colmados de africanos que padecían diferentes epidemias, ${ }^{35}$ recorrió calles y murallas para entregar o pedir limosnas y visitó las casas de los aristócratas enfermos. Además predicó en los suburbios periféricos del puerto, especialmente en Getsemaní, sector que comenzaba a ser habitado por esclavos huidos, prostitutas, marineros y contrabandistas; subió a las embarcaciones para dar la bienvenida a los africanos, participó en juicios civiles y fue amplio colaborador del Tribunal del Santo Oficio de la Inquisición. Los testigos describen un hombre que denunció ante la Inquisición toda práctica que considerara fuera de la verdadera vida cristiana.

\footnotetext{
${ }^{34} \mathrm{El}$ término extranjero aparece entre comillas porque los africanos también eran extranjeros, sin embargo la Corona no los calificaba de esta manera por haber determinado que eran, tan solo, mercancía.

${ }^{35}$ Vale la pena anotar que tanto las epidemias como los tratamientos son descritos con minuciosidad. En ese sentido, el documento es valioso para realizar estudios acerca de la tecnología, la ciencia médica del periodo; o en investigaciones sobre el concepto y uso del cuerpo.
} 
Fruto de su extensa educación en teología, filosofía y ciencia en Colegios de la Compañía, el sentido que Claver dio a la "verdadera vida cristiana" tuvo al menos dos inspiraciones: los razonamientos tridentinos y la literatura sugerida por los jesuitas, muchos de ellos misioneros en India y China. ${ }^{36}$ Esos primeros jesuitas integraron la práctica de la piedad medieval con la innovación de técnicas apostólicas y devocionales. Con suma cautela para no aproximarse al impulso separatista del protestantismo, el prototipo de misionero jesuita era aquel que enmarcara su labor en la tradición católica sin dejar de innovar, de acuerdo al contexto social, la manera más adecuada para evangelizar.

Con este objetivo, los jesuitas mantuvieron el principio de imitar a Cristo base de la práctica cristiana en la Edad Media -, así como la devoción a la Virgen y los santos, las festividades sacras, el pago de indulgencias, la realización de procesiones y peregrinaciones y la importancia del régimen sacramental. Pero, a diferencia de la casi irreflexiva religiosidad medieval, sugirieron la lectura analítica de los humanistas clásicos, el desarrollo de la ciencia, el arte y la tecnología.

Los grandes intelectuales de la Iglesia católica apoyaron el proyecto jesuita de integrar la piedad medieval al humanismo renacentista y así nació la Devotio Moderna.${ }^{37}$ Durante el Concilio de Trento esta forma de devoción se instituyó como la manera más adecuada para establecer una relación con Dios. El estimulo al estudio de la tradición literaria trajo consigo la práctica de la lectura personal, la cual viabilizaba la reflexión en los misterios de la fe. Leer las obras de los místicos y orar en privado hasta alcanzar la contemplación, posibilitó la comunicación entre Dios y el creyente sin la mediación del clero. Pedro Claver es un claro representante de esa tendencia tal como lo muestra el testimonio más amplio del Proceso otorgado por Nicolás González, auxiliar del padre y jesuita de menor rango, quien se refiere a la lectura constante de Claver

Siempre tenía al frente el libro impreso arriba mencionado; y esto lo veía este testigo porque el padre mantenía toda la noche la lumbre encendida en su cuarto. Y viéndolo todo fijo y concentrado en su Creador, no le decía nada por no interrumpirlo en su meditación. ${ }^{38}$

\footnotetext{
${ }^{36}$ CRIVELLER, "Preaching Christ". El libro esta dedicado a este tema.

${ }^{37}$ CRIVELLER, "Preaching Christ", p. 14.

${ }^{38}$ ARISTIZABAL, "Proceso de beatificación", p. 73.
} 
Tal como sugería la devoción moderna, éste y muchos otros testimonios describen un hombre que además de la lectura, dedicó largas horas a la oración individual al punto de alcanzar estados de éxtasis trascendental, quien también organizaba procesiones a la Virgen, repartía medallitas sagradas y realizaba misas de indulgencia. Entender la lógica que existe tras una devoción que mixtura las prácticas humanistas y medievales es importante pues allí nace su concepto sobre los africanos.

\section{Los Ejercicios Espirituales}

La devoción de Claver estaba regida por los "Ejercicios Espirituales". 39 Publicada en 1548, esta obra más importante de Ignacio de Loyola. Los Ejercicios no son un tratado de teología, sino un manual de instrucciones para el crecimiento espiritual del cristiano. Se trata de una manera de conducir la oración en cuatro etapas hacia el misterio de Cristo. El método propone el control paulatido de los sentidos, los sentimientos y los pensamientos con el fin de cultivar una vida espiritual modelada por la figura de Cristo. Consiste, por ejemplo, en fijar la mirada en una imagen de la crucifixión hasta lograr la visualización de este episodio en la conciencia interior. Luego de visualizar el episodio, el devoto debe relacionar su obrar con el sacrificio de Cristo. El objetivo último es dominar el impulso a pecar mientras se alimenta el deseo ser conducido por Cristo. Al parecer Claver seguía a cabalidad esas instrucciones al punto que el mismo Nicolás González declara que

Regulaba y ordenaba su oración según los Ejercicios de nuestro padre San Ignacio, y este testigo lo sabe porque no dejaba nunca de leer dicho libro, observando exacta y puntualmente sus reglas y observaciones para no equivocarse en la oración. ${ }^{40}$

Por otra parte, los Ejercicios Espirituales conservaron el principio medieval por el cual el devoto debía ser un imitador de Cristo. Este razonamiento provenía del libro "Imitatio Christi" escrito por Thomas de Kempis y publicado por

\footnotetext{
${ }^{39}$ LOYOLA, "Obras", p. 181 - 308.

${ }^{40}$ ARISTIZABAL, "Proceso de beatificación", p. 73.
} 
primera vez en 1418. Allí el autor reflexionó sobre la humanidad de Cristo para concluir que su mayor virtud consistió en el sacrificio por el otro siendo la crucifixión la más grande expresión de ese principio. La vida de los cristianos debía asemejar esa virtud al repetir los sufrimientos y renuncias. La idea estimuló en el clero y la feligresía una vida conducida por el martirio, opuesta al placer y a cualquier estímulo sensorial que condujera al goce. En cuanto al ascetismo sensorial, Manuel González, coadjuntor de la Compañía afirma que Claver

Era tan modesto y se mortificaba tanto en el oido, que este testigo no lo vió dedicarse nunca a la música ni a los discursos o historias vanas. Y cuando a veces los escuchaba por necesidad no se divertía con ellos más levantaba su espíritu a Dios y aplicaba todos sus sentidos a la contemplación de las cosas celestiales, permaneciendo como extraño y con los ojos cerrados. Y aunque no era sordo mantenía de ordinario los oidos tapados con algodón para no escuchar ni sentir ninguna cosa mundana. ${ }^{41}$

Clave no solo restringía sus sentidos sino que imitaba literalmente los padecimientos de Cristo. Bartolomé de Torres, rector del Colegio de Cartagena dice que

entró en su celda algunas veces sin llamar y lo encontró con la corona de espinas en la cabeza, otras con una cuerda al cuello, otras en cruz y tuvo por cierto que meditaba en esos momentos los pasos de la Pasión de Cristo Nuestro Señor correspondientes a los objetos que tenía puestos en su cuerpo. ${ }^{42}$

\section{El contacto con africanos como un acto sacrificial}

El Proceso resalta varias veces a Claver como el perfecto imitador de Cristo. Los hermanos jesuitas del Colegio observan que "en toda su vida se crucificó a imitación de Cristo, siendo esta la devoción que siempre y sobretodo

\footnotetext{
${ }^{41}$ ARISTIZABAL, "Proceso de beatificación", p. 74.

${ }^{42}$ ARISTIZABAL, "Proceso de beatificación”, p. 75 Otros apartes refieren la gama de sufrimientos autoinfligidos por el santo: llevaba siempre puesto un cilicio, se alimentaba de comida podrida se despreciaba a sí mismo, acepta el padecimiento de los temblores que lo conduce a la muerte.
} 
prefirió". ${ }^{43}$ El énfasis del testigo es interesante pues deja vera que la imitación del sufrimiento era preferida sobre cualquier otra por el santo, ella era el motor de todas sus acciones. ¿Cabría afirmar entonces que negarse a comer, llevar amarrado un cilicio o aguantar las picaduras de mosquitos, derivaban del mismo impulso que visitar leprosos, lamer las llagas de los virulentos o tener contacto físico con los africanos? Al respecto aparece en el Proceso

Con fortaleza soportó el hedor de los negros y la suciedad e inmundicia de los enfermos, las picaduras frecuentes de los mosquitos, muy abundantes en esta regiones, y otras tribulaciones debidas a los trabajos ya mencionados. Todo lo sufría no paciente, sino alegremente. ${ }^{44}$

Para los testigos era claro: el mayor sacrificio de Claver, tan solo comparable con soportar las picaduras y los enfermos, fue el acercamiento íntimo a los africanos. Diego de Villegas, vecino de Cartagena describe con sorpresa la visita de Claver a los africanos prisioneros

Los abrazaba y acercaba su rostro al de ellos, diciéndoles palabras muy amorosas y tiernas y de gran consuelo [...] Todas estas cosas causaban gran confusión es este testigo, porque las consideraba como acciones que obraba un hombre santo y entregado a Dios, con total desprendimiento de las cosas de la vida y sin importarle el mal olor que desprendían de sus cuerpos. ${ }^{45}$

La asociación entre africanidad, negritud y hediondez es insistente en la fuente. ${ }^{46} \mathrm{El}$ asco llega al punto que las mujeres aristócratas discuten con Claver por recibir africanos en la eucaristía dominical. Al final de la celebración ellas se acercaban para pedirle que no permitiera entrar a los africanos a las mismas eucaristías que ellas asistían pues "no podían aguantar el mal olor que los negros exhalaban de sus cuerpos". ${ }^{47}$ De acuerdo con este episodio, podemos afirmar

\footnotetext{
${ }^{43}$ ARISTIZABAL, "Proceso de beatificación", p. 70.

${ }^{44}$ ARISTIZABAL, "Proceso de beatificación”, p. 25.

${ }^{45}$ ARISTIZABAL, "Proceso de beatificación", p. 268.

${ }^{46}$ ARISTIZABAL, "Proceso de beatificación", p. 218.

${ }^{47}$ ARISTIZABAL, "Proceso de beatificación", p. 117.
} 
que ya desde mediados del siglo XVII la sociedad cartagenera comienza a restringir el acceso de los africanos y sus descendientes a ciertos espacios y posibilidades.

\section{Rasgos de la Devotio Moderna en Claver}

Como vimos arriba, Claver practicaba la devoción moderna en el sentido de creer que la lectura conducir hacia Dios, entre más letrada fuera una persona, mayor acercamiento y raciocinio de las cosas de Dios alcanzaría. La historia del diario de Alonso Rodriguez, su mentor, revela su postura al respecto. Claver regala el diario manuscrito de Rodríguez al Colegio de Tunja

la razón que tuvo para pedir licencia al padre General para dejarlo en el Noviciado fue porque, leyéndolo los novicios que se educaban en esta casa, se embebieran en él, se les grabara en el alma el espíritu del hermano Alonso y obtuvieran el mismo provecho espiritual que había obtenido él con su lectura. ${ }^{48}$

Esta postura también se presenta en Los Ejercicios Espirituales cuando Loyola afirma que la lectura era la única práctica que permitía a la persona arraigar el conocimiento que podía olvidarse. ${ }^{49}$ La lectura era el mecanismo ideal para fijar en el intelecto las reflexiones. Por otra parte, leer daba sentido a la oración. Si bien el clero había sido la guia espiritual del devoto en el medioevo, en el Renacimiento la lectura personal había ocupado ese lugar. Leer los cristianos ejemplares: santos, mártires y grandes teólogos se convirtió en un deber. Claver por ejemplo mantenía en su celda Los Ejercicios Espirituales, el Nuevo Testamento, las meditaciones de San Bernardo, los libros de Ignacio de Loyola y

antes de la oración leía el punto que había de meditar en el libro del padre Luis de la Puente de la Compañía de Jesús y en los libros del padre Alonso de Andrade de la misma Compañía, o en el Camino de Perfección y los Avisos Espirituales de la madre Santa Teresa de Jesús’ comentados por el mismo padre Andrade. ${ }^{50}$

\footnotetext{
${ }^{48}$ ARISTIZABAL, "Proceso de beatificación", p. 76.

${ }^{49}$ LOYOLA, "Obras”, p. 197 - 199.

${ }^{50}$ ARISTIZABAL, "Proceso de beatificación”, p. 73.
} 
Pero la posibilidad de acercarse a Dios no era el único beneficio de la lectura. Esta también permitía el acceso al razonamiento de los pensadores más entendidos como Aristóteles o Platón. Retomar los sabios de la antigüedad facultaba el desarrollo de las artes, las ciencias, la política, la tecnología. En todo sentido leer era una actividad elevada.

Sin embargo, parece que la lectura no era una actividad que correspondía a los africanos. Al defender por ejemplo que se administrara con frecuencia la eucaristía a los "negros" el santo

respondía con toda mansedumbre, modestia y particular humildad, con la parábola del evangelio de aquel rey que hizo el convite esplendoroso y habíendose excusado algunos, ordenó a los sirvientes que condujeran al convite a lo ciegos, locos y lisiados. Y añadía que adivinaran a quienes se refería: a los pobres negros, esclavos y abandonados de esta ciudad. También defendía esta opinión suya con un paso de la Sagrada Escritura, en el cual se dice que Dios salvará al hombre y al asno, entendiéndose por asnos a los negros por su gran incapacidad y poca inteligencia en las cosas divinas. ${ }^{51}$

Locos, lisiados, ciegos y asnos para las cosas divinas son las metáforas con las cuales la sociedad cartagenera asociaba a los africanos, al menos son las que Nicolás González le atribuye al santo. Al decir asnos, el documento implica que los africanos tenían la imposibilidad de razonar, meditar en los misterios de la fe y acceder al perfeccionamiento espiritual que alcanzaban los europeos ¿Sería la carencia de escritura en las sociedades africanas la base de este juicio? ¿Podríamos pensar que desde la postulación del humanismo renacentista los grupos sociales ágrafos, comenzaron a ser considerados menores que los letrados?

El impedimento de los africanos para alcanzar el perfeccionamiento espiritual ya había sido trazado por Alonso de Sandoval en la obra Naturaleza, policia sagrada i profana: costumbres i ritos, disciplina i catechismo evangelico de todos etiopes. ${ }^{52}$ La historiadora Luz Adriana Maya Restrepo realiza un amplio

\footnotetext{
${ }^{51}$ ARISTIZABAL, "Proceso de beatificación", p. 79.

${ }^{52}$ SANDOVAL, Alonso, "Naturaleza, policia sagrada" 1627.
} 
estudio de la obra escrita por Sandoval. Su estudio muestra que la obra es fundamental para comprender la singularidad de las culturas africanas en el XVII pues allí se delinea una "topografía de lo espiritual africano". ${ }^{53}$ El término etiope, con el cual Sandoval denomina los africanos era asociado a la monstruosidad física y espiritual, "así a principios del siglo XVII, la exclusión tomaba forma en una prédica cuyo protagonista era el etíope monstruoso: su cuerpo estaba degenerado por el calor y su alma por el dominio del demonio y el pecado. ${ }^{54}$ Sandoval relaciona la monstruosidad espiritual con la idolatría, es decir, con sociedades que se mantienen en los errores de la gentilidad. Maya concluye que dicho concepto se convierte en el estímulo principal para evangelizar esa población. ${ }^{55}$ De hecho, Claver fue enviado al puerto con el propósito explícito de continuar la obra de Sandoval de "alejar a los negros del culto de su falsa religión". ${ }^{56}$

Claver y Sandoval comparten el motivo por el cual los africanos debían ser conducidos a América. En ese nuevo continente los africanos conocerían al "verdadero Dios" y practicarían lo que los jesuitas consideraban su única vocación: servir. El santo mantuvo repetidas conversaciones con los africanos donde

les decía que se alegraran mucho por haber llegado a países de españoles, que era una gracia que les había hecho Dios, porque se harían cristianos e hijos suyos; que los blancos no los traían a matarlos y hacer polvos de ellos, cosa de la cual estan convencidos los negros, sino solo para que les sirviesen; y que si ellos lo hacían con diligencia, recibirían muchos regalos y los vestirían muy bien. ${ }^{57}$

\section{Prácticas de Claver para conducir a la conversión}

Al tiempo que los habitantes del puerto elaboraban el concepto de los africanos, el Obispo de Sevilla Don Pedro de Castro y Quiñonez escribía en 1614 las instrucciones para preparar a "negros, moros y turcos" para recibir el

\footnotetext{
${ }^{53}$ MAYA RESTREPO Luz Adriana. Brujería y reconstrucción de identidades entre los africanos y sus descendientes en la Nueva Granada, Bogotá, Ministerio de Cultura, 2005, p. 219.

${ }^{54}$ MAYA. "Brujería y reconstrucción”, p. 238.

${ }^{55}$ MAYA. "Brujería y reconstrucción”, p. 303.

${ }^{56}$ ARISTIZABAL, "Proceso de beatificación”, 2002, p. 10 y 65.

${ }^{57}$ ARISTIZABAL, "Proceso de beatificación”, p. 219.
} 
bautismo. Las disposiciones presentaban el orden en el cual los misterios debían ser enseñados a esas poblaciones. ${ }^{58}$ En Cartagena, Pedro Claver sigue el orden designado por Castro, pero adiciona principios formulados en 1556 por Loyola quien planteaba dos aspectos importantes del apostolado: atraer hacia Dios y hablar la lengua de quienes se iba a evangelizar. ${ }^{59}$ Con esa estrategia buscaba generar la auténtica conversión de los nuevos cristianos motivada por la convicción y no por la imposición.

En la Edad Media la Iglesia negaba la existencia de cualquier "conocimiento" fuera del libro sagrado: la Biblia. Omitir ese libro era sinónimo de negar la verdad. Así, el adoctrinamiento de poblaciones desconocedoras del evangelio consistía en destruir toda razón o práctica religiosa anterior. Al procedimiento se le denominaba “Tabula Rasa”. Ya en el periodo renacentista Erasmo de Rótterdam, se pregunta porque Jesucristo impulsó la conversión de sus discípulos y concluye que esa capacidad estaba asociada al hecho de rebajarse y acomodarse, aún siendo Dios, a la vida de la gente común. Con esto Jesús consiguió ser comprensible y accesible a todos.

Loyola encuentra razón en la postura de Rotterdam y propone a los jesuitas transformar la idea de Tabula Rasa por la "Accomodatio". ${ }^{60}$ El nuevo principio implicaba que el evangelizador se sumergiese en la sociedad foránea, se moldease a la experiencia de los demás, entendiera esas tradiciones y predicara de acuerdo a la capacidad mental, cultural y ética del Otro. Esto con el fin de estimular la verdadera convicción acerca de Cristo. El objetivo era adoptar lengua y costumbres locales para lograr explicar en términos nativos los principios del cristianismo. Seguidor de esta práctica, Mateo Ricci S.J. entra en la corte china, aprende la lengua, e inclusive busca conciliar el confucianismo con el cristianismo. ${ }^{61}$ Pedro Claver se nutre de ese tipo de ejemplos mientras reflexiona el modo de "acomodarse" a los africanos que estaban llegando a Cartagena de Indias.

\footnotetext{
${ }^{58}$ ARISTIZABAL, "Proceso de beatificación", p. 91. Primero se debía enseñar el misterio de la Santísima Trinidad, luego, la Encarnación del Hijo de Dios en una Virgen, tercero, la muerte y pasión en la Cruz, cuarto, la Resurrección y por último, el juicio final y la resurrección.

${ }^{59}$ LOYOLA, "Obras", p. 1083.

${ }^{60}$ LOYOLA, "Obras", p. 752 - 753.

${ }^{61}$ CRIVELLER, "Preaching Christ”. A lo largo del libro se explica la labor evangelizadora de Ricci.
} 


\section{La evangelización realizada por Claver}

Bajo los postulados de esa arma de persuasión Claver hizo tres propuestas para cristianizar a los africanos. Primero, entrenó intérpretes, segundo, usó la gestualidad para explicar el Evangelio, tercero, encauzó el centro de la fe en la familia. Así buscó ligar los africanos a un nuevo linaje donde el Dios cristiano era padre, Jesús era su hermano y Claver la figura paterna en la tierra. La fuerza de la diversidad lingüística, la corporalidad y los lazos de parentesco en esas culturas africanas obligaron al jesuita a incluir esos aspectos en su estrategia de conversión.

\section{El entrenamiento de intérpretes}

Los interpretes que aparecen en el Proceso son 29, es decir, el 31\% del total de esclavos que allí se nombran (ver Tabla 1). Ignacio Albañil y Andres Sacabuche, ambos de Angola, hacen parte de los principales testigos y dicen haber desempeñado el oficio por más por más de 30 años. Sus extensas declaraciones revelan dos de sus tareas: evangelizar y servir de traductores en los juicios inquisitoriales. Los jóvenes, todos varones, eran elegidos antes que los barcos anclaran en el puerto. El jesuita junto con un grupo de intérpretes entraba en las fosas y preguntara quienes de ellos hablaban más de dos lenguas. Luego solicitaba al Colegio la compra de esa persona con el único propósito de servirle.

Una de las riquezas del Proceso está en el detalle para describir la vida y la proveniencia de estos africanos. Ellos vivían en las habitaciones traseras del Colegio, comían en la cocina y ayudaban en los oficios de limpieza, recolección de limosna, servían de músicos en las celebraciones eucarísticas y elaboraban las medallas y rosarios que Claver regalaba a otros africanos. Los apellidos, los oficios y los datos sobre su vida sirven para reconstruir los trayectos de vida de estas personas. Es el caso de Francisco Yolofo quien declara haber llegado a la ciudad alrededor del año 1632, en la embarcación de Pedro Vera, ya sabiendo portugués. Francisco resulta un caso atractivo a posteriores investigaciones pues era mahometano ${ }^{62}$ y tardó varios años para convertirse a la fe cristiana, sin embargo, como ya sabía hablar portugués, sirvió como intérprete en el juicio

\footnotetext{
${ }^{62}$ ARISTIZABAL, "Proceso de beatificación", p. 88 En el proceso se le identifica también como "turco".
} 
del palenque del Limón. El mismo Francisco afirma en su declaración que uno de los negros del palenque del Limón se llamaba Juan Yolofo y

no pudiendo el padre confesarlo sin el intérprete, encontró a este testigo que sabía la lengua portuguesa y lo llevó consigo a la cárcel para que le sirviera de intérprete; (...) Y por haber servido este testigo en ese ministerio el padre Claver, se aficionó a él y logró que el rector de este Colegio llamado Juan Manuel, quien ya ha muerto, lo comprara como esclavo para que sirviera al padre cuando se ofreciera la ocasión del ministerio como intérprete de la lengua yolofa

Lo increíble es que Francisco no solo sabe portugués y yolofo sino también mandinga y verdesí pues más adelante afirma,

En cierta ocasión, estando un negro de nación mandinga muy enfermo en casa de Ventura Puertollano quien vivía en aquel tiempo en la calle que está arriba del convento de Santo Domingo que llaman de Alcivia y el negro se llamaba Juan Mandinga, llamaron al padre para que lo confesara; y él llevó a este testigo consigo para que sirviera de intérprete, porque no solo sabe la lengua yolofa sino también la mandinga y verdesí. ${ }^{63}$

El caso de Yolofo permite observar el alcance de la fuente al explicitar el lugar donde moraban los intérpretes y sus recorridos dentro de la ciudad. Asimismo suscita preguntas interesantes para la historiografía. El poliglotismo de Francisco y varios otros testigos indicaría que esas personas migraban dentro de África y convivían con sociedades que hablaban otras lenguas. Ambas opciones sugieren del cosmopolitismo de esas culturas y permiten dimensionar la amplitud de las redes comerciales existentes. De esta manera el Proceso no solo arroja información sobre las la diversidad y la proveniencia de las prácticas expresas en Cartagena, sino que aporta datos para reconstruir trayectos de esos africanos del siglo XVII.

Los apellidos de los esclavos en América han sido interpretados por los historiadores del tráfico trans-Atlántico como designaciones referidas a cuatro

${ }^{63}$ ARISTIZABAL, "Proceso de beatificación", p. 310. 
aspectos: la cultura de origen, el puerto de embarque, la lengua materna o la zona de proveniencia. De acuerdo con esto, los apellidos son útiles aunque confusos porque los europeos nunca discriminaban a cual de las anteriores variables se referían. El Proceso en cambio brinda una correlación directa entre el apellido y el intérprete, quien traducía determinadas lenguas. En ese sentido, da una información más fiel sobre los orígenes culturales.

Los datos estadísticos sobre los intérpretes empleados por Claver apuntan al objetivo de conocer la gama de lenguas y culturas africanas representadas en Cartagena. Es indudable que si Claver prefería un mayor número de intérpretes Angola, Biafra, Bran y Folupo según exhibe la Tabla 1, esa población era más numerosa en la ciudad.

Del total de intérpretes cuatro son Angola, y otros cuatro son Congo, Monzolo y Yarca (aquí asociados a los Yaka) todos originarios de África CentroOccidental. Ellos constituyen el 23\%. ${ }^{64}$ La misma composición demográfica presenta el juicio llevado a cabo contra el palenque de Limón entre 1633 y 1644 (donde Claver sirvió de confesor) donde cuatro de los africanos sentenciados son Anzico, Angola, Congo y Malemba, ${ }^{65}$ todos ellos provenientes de sociedades ubicadas por la historiografía en África Centro-Occidental. Esos condenados por el secuestro de los hijos de hacendados y nativos afirmaron que muchos, aunque no todos los habitantes del palenque, tenían la misma procedencia. Esto sugiere que en la primera mitad del siglo XVII, había un mayor número de africanos en Cartagena provenientes de la región Centro-Occidental dato corroborado en las estadísticas arrojadas por los historiadores del tráfico trasatlántico. ${ }^{66}$

En cuanto a los Biafra, reconocemos que eran provenientes del sur oeste de Nigeria, hoy incluidos entre las poblaciones Ibo. Sin embargo, no podemos

\footnotetext{
${ }^{64} \mathrm{El}$ apellido Angola es una caja negra pues era el nombre del cuchillo ritual utilizado por varias culturas de esa región de África; pero además, para mediados del siglo XVII Angola servía para denominar la amplia colonia portuguesa. Para ampliación del tema ver Ngola. The Weapon as Authority, Identity, and Ritual Object in Sub-Saharan Africa,Cambridge, MA, Hurst Gallery, 1997, p. 38. Citado por McKNIGHT, "Confronted rituals”, p. 17.

65 "Testimonio de los proçessos y castigos..." T. 351, 353, 465.

${ }^{66}$ CURTIN Philip, The Atlantic Slave Trade a Census. Madison, University of Wisconsin Press, 1969, p. 109; VERGER, Pierre. Fluxo e Refluxo, Do tráfico de escravos entre o Golfo do Benin e a Bahia de Todos os Santos, dos séculos XVII a XIX. São Paulo, 1987, p. 27.
} 
afirmar que para el siglo XVII lo fueran pues los Ibo han pasado por intensos procesos de absorción de sociedades circundantes, muchas de ellas nómadas.

Sucede lo contrario, con aquellas sociedades africanas que aparecen en el Proceso aunque no requirieron de intérprete como Cabo Verde, Viozo, Carabalí, Mandinga y Lape. Es posible que esos pueblos conocieran de antemano alguna lengua europea, como en el caso de las personas venidas de Cabo Verde donde los portugueses tenían una amplia participación en la sociedad. ${ }^{67}$ Otra opción es que fueran personas reacias a colaborar en la cristianización porque eran musulmanes, entre ellos podrían estar los Mandingas o los Fulupos. De acuerdo con la información del Proceso, estos dos nombres podrían referirse a la misma sociedad pues, Juan Mandinga, aparece como negro esclavo de lengua Folupo. De no ser así, sugiere ser Mandinga una denominación para los conversos al Islám. Una tercera opción señalaría que las poblaciones estuvieran dejando de llegar al puerto a causa de la extinción de sus culturas o porque eran muy difíciles de capturar. Tres hipótesis que se dejan abiertas a futuras investigaciones.

Según elogian los jesuitas, el esfuerzo de los intérpretes por evangelizar en sus lenguas vernáculas confería cercanía y mejoraba la comprensión de la nueva religión. Sin embargo, al ser los africanos quienes enseñaban los principios cristianos de fe, podrían buscar las figuras narrativas, metáforas y conceptos para nombrar y delinear la cosmogonía cristiana en sus referentes culturales. Así las cosas, la información teológica suministrada por los africanos atravesaba por el tamiz de sus creencias y léxicos, lo cual sugeriría la modificación o adición de conceptos Yolofo, Angola, Biafra, Bran, etc. a la doctrina católica.

Por último, Splendiani afirma que Claver sirve al Tribunal de la inquisición pues "él mismo hablaba angolés". ${ }^{68}$ Esto ampliaría el rango del interés de Claver por las lenguas africanas y daría una doble vía a los intercambios lingüísticos en Cartagena. Sin embargo, habría que investigar la veracidad de este hecho en los juicios inquisitoriales, pues no aparece ninguna información al respecto en el Proceso.

\footnotetext{
${ }^{67}$ COSTA E SILVA, Alberto da, A Enxada e a Lança: a África antes dos portugueses. Rio de Janeiro: Nova Fronteira, 1996.

${ }^{68}$ SPLENDIANI, Anna María, Cinquenta años de inquisición en Cartagena de Indias, Tomo I, Bogotá, CEJA e Instituto Colombiano de Cultura Hispánica, 1976.
} 


\section{El uso de la gestualidad}

El segundo rasgo que caracterizó el acomodamiento practicado por Claver fue el uso de la gestualidad. De acuerdo con los testigos, el jesuita intenta generar el deseo de conversión por medio de gestos de misericordia -obsequios, visita a los enfermos, abrazos-, imágenes, repeticiones y actuaciones, al tiempo que nunca se propone alfabetizar las poblaciones africanas. Según Nicolás González, Claver "solía decir que, para atraer a estas gentes había que hablarles primero con las manos haciéndoles regalos con caridad y después con la lengua instruyéndolos con amor". ${ }^{69}$

Los testigos son claros en mostrar que Claver discriminaba el procedimiento para instruir a cada sector de la sociedad cartagenera. Entregaba libros de crecimiento espiritual a Nicolás, su compañero de misión, y obligaba a leer la pasión de Cristo a Pedro Calderón, familiar del Tribunal de la Inquisición. ${ }^{70}$ Mientras tanto, teatralizaba los conceptos a los africanos, al considerar que era lo único que podían entender. Esto señalaría la participación del jesuita en el diseño de acciones excluyentes hacia los africanos. Al enseñar sobre el arrepentimiento actuaba el concepto con golpes de pecho y repeticiones de una misma frase

terminaba el padre Claver estos discursos y exhortaciones con un acto de contrición muy fervoroso que hacía junto con sus penitentes, sacando el Cristo Crucificado que llevaba en el pecho y teniéndolo levantado con la mano izquierda, golpeándose fuertemente con la derecha el pecho. Decía entonces muchas veces ‘señor, yo te quiero mucho'; de lo cual se seguía que todos los presentes hacían lo mismo y se movían a verdadero dolor y arrepentimiento de todos sus pecados con verdadero propósito de enmendarse, clamando todos juntos y dicíendo y repitiendo lo que le padre les decía, etc. ${ }^{71}$

El santo utilizaba las mismas estrategias para enseñar sobre la importancia de los sacramentos, el bautizo, la confesión y el casamiento. Se emocionaba

\footnotetext{
${ }^{69}$ ARISTIZABAL, "Proceso de beatificación", 2002 p. 89, 14 y 18. Ver también el procedimiento suyo para mover los corazones p. 69.

${ }^{70}$ ARISTIZABAL, "Proceso de beatificación", p. 71.

${ }^{71}$ ARISTIZABAL, "Proceso de beatificación”, p. 69.
} 
tanto en medio de la catequesis que se lanzaba al piso, se rasgaba la ropa, lloraba, gritaba y escupía.

El que Claver utilizara el recurso corporal para evangelizar serviría al propósito de agregar un sentido católico al cuerpo de los africanos. No obstante, las manifestaciones corporales africanas continuaron vigentes en el puerto al punto de requerir la intervención del tribunal de la inquisición para detener danzas, contactos sexuales y rituales ejercidos no solo por los africanos, sino por sus descendientes. Al respecto, Maya Restrepo propone el concepto de "corp-oralidad" para mostrar cómo los esclavizados llegaron con una corporalidad colmada de memoria - tradición oral - e identidad. Una memoria que se enraizó a lo largo de la colonia y que sirvió en la elaboración de nuevas identidades cimarronas y afrodescendientes. Al respecto es importante mencionar la insistencia del padre en evitar que los africanos anduvieran desnudos por Cartagena. En oposición a las ideas africanas sobre el cuerpo, para Claver ese acto era un signo de deshonestidad, pecado y escándalo. El padre inclusive se quitaba su manteo para cubrir los bozales desnudos y tapaba los cuerpos desnudos de las imágenes sacras antes de empezar a evangelizar.

De la misma manera las negras llegaban desnudas. El venerable siervo de Dios pedía vestidos de limosna, para atenderlas en forma decente y que no aparecieran en público en forma deshonesta. Y puesto que acostumbraba usar imágenes para instruirlos en la fe, como dijimos, a una de ellas que representaba el infierno, y algunas de las figuras impresas se veían sin vestidos, el padre por honestidad las cubrió con tinta negra. ${ }^{72}$

\section{El Bautizo}

La mejor ilustración sobre los procesos de evangelización de Claver se refiere a la preparación para el bautismo. Esta comenzaba cuando Claver entraba a las fosas de las naves para entregar naranjas. Dentro del barco aun sin encallar, escogía los más enfermos y les preguntaba si ya habían sido bautizados. En caso de no poder responder y si estaban muy enfermos los bautizaba

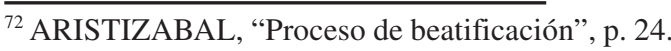


"sub conditione". ${ }^{73}$ Luego preguntaba, por medio de los intérpretes, los lugares de provenciencia y los clasificaba según el manual escrito por Sandoval para saber quienes conocían algo del cristianismo, quienes venían de tierras musulmanas y quienes servirían de intérpretes. En tierra los conducía a los patios de las grandes casonas donde los retenían antes de ser vendidos. Allí preparaba un altar, separaba mujeres de hombres y los distribuía en esteras, bancos y pedazos de madera. Los intérpretes eran acomodados en asientos frente a los recién llegados.

Para comenzar la enseñanza, Claver sacaba de su pecho un crucifijo de bronce y les decía, a través de los intérpretes, que ese señor se había puesto en una cruz para pagar por los

vicios y pecados que habían cometido en su país. [...] Al decir esto el santo se golpeaba la parte izquierda del pecho y hacía que los africanos hicieran lo mismo mientras repetían 'Jesucristo Hijo de Dios, tu eres mi padre y mi madre, yo te amo mucho, me duele en el alma haberte ofendido'. ${ }^{74}$

La segunda sesión estaba dedicada a explicar el sentido de la conversión,

les decía que así como la serpiente muda de piel, ellos debían mudar de vida y costumbres, desnudándose de la gentilidad y de sus vicios; de manera que hasta debían perder la memoria de todas esas cosas. Y mientras decía estas palabras, colocando el crucifijo sobre el pecho, se pasaba las manos de la frente a la cintura rasguñándose y como si quisiera arrancarse la piel; con lo cual los esclavos hacían los mismo. Enseguida repetía la misma acción sobre los brazos y otras partes del cuerpo, imitándolo todos en esta acción con tanto fervor que parecía que se despojaban verdaderamente de su piel y la arrancaban de sí y la escupían en señal de que se despojaban del antiguo Adán y de sus pasiones y vicios, y se vestían del hombre nuevo, Cristo, y de sus virtudes, profesando la ley evangélica que él enseñó. ${ }^{75}$

\footnotetext{
73 "sub conditione" era un permiso para bautizar a quienes estaban impedidos de responder si ya habían sido bautizados o no.

${ }^{74}$ ARISTIZABAL, "Proceso de beatificación”, p. 92.

${ }^{75}$ ARISTIZABAL, "Proceso de beatificación”, p. 92 las comillas son mías.
} 
La instrucción duraba varios días. Cuando terminaba los llevaba a la catedral y les preguntaba, por medio de los intérpretes, si deseaban recibir o no el sacramento. ${ }^{76}$ Finalmente, les colgaba una medalla con Jesús de un lado y María del otro, para distinguir los que estaban bautizados de los que no. En los siguientes días controlaba que los esclavos catequizados se estuvieran persignando bien, luego les enseñaba los principios de la confesión y las hacía repetir el acto de contrición. ${ }^{77}$

\section{La metáfora de la familia}

El tercer rasgo de la "Accomodatio" de Claver fue el uso del parentesco como metáfora central para ilustrar los principios del cristianismo. No solo mostraba que Dios era un padre y Jesus un hermano, sino que él mismo podría ocupar el lugar de padre. Según González "Para administar el bautizo se ponía en la mitad del navío rodeado de los esclavos, y por medio de los intérpretes les decía que había venido para ser el padre de todos y para que fueran bien recibidos en la tierra de los blancos". ${ }^{78}$

Dado que eran despojados de sus familiares y arrojados a un lugar de extraños, la figura de Claver debía generar un impacto fuerte para los recién llegados. Después del santo morir le preguntaron a algunos africanos si se sentían tristes

A lo cual contestaron los pobres que si hubieran muerto sus padres y madres no les causaría tanta pena como les causaba la pérdida del padre Pedro Claver; y que estaban muy dolidos y afligidos por una pérdida tan grande como la del padre, que era padre y madre de todos y cada uno en particular. ${ }^{79}$

\section{Las imágenes}

Por ultimo Claver utilizaba las representaciones pictóricas pues "explicando esta y otras imágenes semejantes llevaba a los negros a la fe cristiana en forma

\footnotetext{
${ }^{76}$ ARISTIZABAL, "Proceso de beatificación", p. 94.

${ }^{77}$ ARISTIZABAL, "Proceso de beatificación”, p. 95.

${ }^{78}$ ARISTIZABAL, "Proceso de beatificación", p. 87.

${ }^{79}$ ARISTIZABAL, "Proceso de beatificación”, p. 247.
} 
mas fácil que con otros sermones o razonamientos" ${ }^{80}$ La cita insiste en el prejuicio de Claver referido a la imposibilidad de los africanos para comprender la fe desde la razón. Basta ahora con señalar el tipo de figuras que utilizaba para darse cuenta de otro componente de su adoctrinamiento: el miedo. En la imagen

estaba representada un alma que ardía en las llamas vivas con algunos demonios alrededor que la atormentaban. Y la explicaba diciendo que era el alma de alguno de aquellos negros que había muerto en sus países sin el bautismo [...] y que debían agradecer mucho a Dios por haberlos llevado a los países de los católicos donde se harían cristianos. ${ }^{81}$

\section{PERSISTENCIA DE LAS TRADICIONES AFRICANAS EN EL PUERTO}

Claver pasaba largas jornadas verificando la persistencia en la práctica de los sacramentos y las oraciones por parte de los africanos. No obstante, encuentra en Getsemaní, suburbio poblado por los africanos y sus descendientes, múltiples expresiones culturales fuera del marco de la fe católica. Los testimonios afirman que el padre cruzaba casi diariamente el puente de San Francisco y se dirigía a la Plaza de la Yerba donde se agregaba la gente "negra". Al cruzar constataba que los africanos mantenían "los vicios de su gentilidad traídos desde su tierra natal", el santo se enfurecía sacaba su disciplina y latigaba desde su caballo a quien estuviera a su paso.

Aquí el Proceso es elocuente en señalar la persistencia de expresiones tales como los toques de tambor, los juegos de dados, "joroba", boliche, los bailes nocturos, el consumo de guarapo, la venta de frutas o tejidos, la plática de un hombre y una mujer en la calle y sobretodo las juntas de lloros cuando moría alguno. La descripción de estos eventos muestra que las prácticas africanas se reedificaron y renovaron en el puerto no obstante la intensiva evangelización del padre.

\footnotetext{
${ }^{80}$ ARISTIZABAL, "Proceso de beatificación", p. 22 y p. 69.

${ }^{81}$ ARISTIZABAL, "Proceso de beatificación”, p. 92.
} 


\section{Persistencia de bailes y lloros}

Entre las prácticas más interesantes de analizar se encuentran los bailes

Cuando en las plazas y calles encontraba algún baile de los negros y negras, si llegaba de improviso sin que lo vieran los que bailaban, sacaba su disciplina y algunas veces el crucifijo de bronce que como se ha dicho llevaba siempre consigo, y con la disciplina los dispersaba teniendo el crucifijo levantado en la mano; y los negros huían como si hubiera entrado en el baile un toro muy furioso, dejando los tambores y otros instrumentos de sus bailes. ${ }^{82}$

Otro episodio narra "que cuando sacaba el crucifijo y azotaba con la disciplina a los negros que bailaban, era porque veía algunos espíritus malignos que en esos bailes incitaban a los negros". ${ }^{83}$ De acuerdo con este fragmento, los bailes en la Plaza de la Yerba no eran expresiones corporales cotidianas a los ojos de los europeos. Allí aparecían unas entidades espirituales distintas. Este cuadro sugiere semejanzas con prácticas vigentes en distintas culturas de África Central y Occidental y abre el campo para investigaciones futuras al respecto.

Por supuesto, los testigos del Proceso que hacían parte del Tribunal de la Inquisición comparten la obsesión por exterminar los bailes y lloros del puerto,

Sabe este testigo, por haber sido durante veinte y cinco años bargel mayor del juzgado eclesíastico, que el padre Claver hizo un gran esfuerzo y empeño con los señores obispos y ordinarios de este obispado a fin de suprimir cierta reunión que hacen los negros ya adoctrinados, de noche, que ellos llaman lloros, o como dicen amanecimientos. En ellos se junta una gran cantidad de negros y negras a bailar toda la noche según la costumbre de sus tribus, con tambores. Estos actos se aproximan mucho a los ritos y supersticiones de los gentiles y en ellos se hacen grandes ofensas a Dios Nuestro Señor. ${ }^{84}$

\footnotetext{
${ }^{82}$ ARISTIZABAL, "Proceso de beatificación”, p. 191 otra referencia al mismo tema en p. 195.

${ }^{83}$ ARISTIZABAL, "Proceso de beatificación", p. 191.

${ }^{84}$ ARISTIZABAL, "Proceso de beatificación", p. 196.
} 


\section{El santo en el contexto social de Cartagena}

Muchos investigadores, entre ellos, Roberto Arrázola, ${ }^{85}$ Maria del Carmen Borrego Pla ${ }^{86}$ y Maria Cristina Navarrete,${ }^{87}$ conciden en mostrar la situación de los africanos en el puerto como una población amenazante para los europeos. A comienzos del siglo XVII se registran los más grandes apalencamientos, fugas y levantamientos armados contra el puerto. Solo hay que recordar la gran insurrección de Benkos Bioho, ${ }^{88}$ el citado juicio a los cimarrones del Limón por el descuartizamiento de varios españoles ${ }^{89}$ y los variados casos denunciados ante el Santo Oficio de la Inquisición, ${ }^{90}$ para observar cómo comenzaba a concretizarse la amenaza. Los análisis muestran la impaciencia de los europeos pues no existía una estrategia para calmar los ánimos libertarios de los africanos.

$\mathrm{Al}$ ambicionar el adoctrinamiento de los africanos, Pedro Claver entra a jugar un papel en la consolidación identitaria y política de los sectores europeos del puerto. Arriba explicamos el problema referido al monopolio comercial de los portugueses al dominar los canales del tráfico y poseer minas de oro y plata dentro del continente. ${ }^{91}$ En los testimonios del Proceso aparece con claridad la división de los europeos en cuanto al status social, el lugar de origen, el oficio y la cantidad de propiedades del sujeto. ${ }^{92}$ Los datos son suficientes para afirmar que familias no españolas eran entraban en el círculo de las más adineradas y poderosas. La familia Blanquecer de Loaysa, de origen flamenco o los Villalobos Tovar de Portugal, representan este grupo. Los estudios realizados por Antonino Vidal Ortega analizan los testamentos de esta última familia y prueban que Vicente, cabeza de familia, había comprado el cargo de alguacil a los funcionarios de la corona. ${ }^{93}$

\footnotetext{
${ }^{85}$ ARRÁZOLA, Roberto. Palenque primer pueblo libre de América, Bogotá, Todo Impresores, 1986.

${ }^{86}$ BORREGO PLÁ, Maria del Carmen, Palenques de negros en Cartagena de Indias a finales del siglo XVII, Sevilla, Escuela de Estudios Hispano-americanos, 1973.

${ }^{87}$ NAVARRETE Maria Cristina, Cimarrones y palenques en el siglo XVII, Cali - Colombia, Universidad del Valle, 2003, p. 96.

${ }^{88}$ NAVARRETE, “Cimarrones y palenques”, p. 64 y FRIEDEMANN, Ma Ngombe, 1987, p. 51.

89 “Testimonio de los proçessos y castigos...” T 270, 282, 289, 992, 997.

${ }^{90}$ MAYA. "Brujería y reconstrucción", p. 499 - 672.

${ }^{91}$ NAVARRETE, "Historia social del negro", p. 115 - 123.

${ }^{92}$ ARISTIZABAL, "Proceso de beatificación”, Índice de Personas p. 571 - 593

${ }^{93}$ VIDAL ORTEGA, “Cartagena de Indias”, p. 135 - 145.
} 
En vista de la imposibilidad para controlar ese poderío por medios legales o económicos, las familias españolas del puerto optaron por plantear la disputa en otros términos, esta vez sociales y religiosos. Comenzaron a alegar que la población portuguesa estaba recién conversa, era de ascendencia judía y mantenía ciertos rituales y creencias propias de su antigua devoción. Según los análisis Maria Cristina Navarrete, el establecimiento del Santo Oficio de la Inquisición en 1610, tuvo como excusa la obligación de extirpar las herejías de los portugueses judaizantes, mientras ocultaba la urgencia de controlar las riquezas adquiridas por esas familias

la persecución a los portugueses judaizantes estuvo ligada al enfrentamiento entre burguesía y aristocracia. Los portugueses monopolizaron segmentos del comercio en España y la totalidad del tráfico de negros, esto generó un fortalecimiento de este sector de la sociedad mirado con rechazo por la nobleza y por el resto de la burguesía. ${ }^{94}$

Vilar Vilar corrobora esta tesis cuando afirma

sobretodo se intensificó la llegada de portugueses amparados en la trata negrera, con el consiguiente deterioro para la fe, por la ascendencia judía de muchos de ellos. Según Domínguez Ortíz, esa fue una de las causas que motivó la creación del Tribunal de la Inquisición en 1610.95

Según esa historiadora, la década de 1630 fue el momento más agudo de esta lucha. El combate contra la herejía conduce a la confiscación de grandes fortunas familiares e incluso al destierro de algunas de estas familias. Al ser partícipe en los procesos judiciales del Santo Oficio de la Inquisición Pedro Claver fue uno de sus protagonistas. ${ }^{96}$ Siendo bastión del catolicismo, ganar el favor del jesuita significaba evitar un juicio inquisitorial. Esta deducción deriva de las múltiples intervenciones dentro del Proceso donde se resaltan las "grandes" sumas que las familias portuguesas invertían en el santo. No solo regalaban

\footnotetext{
${ }^{94}$ NAVARRETE, "Historia social del negro", p. 117.

${ }^{95}$ VILA, "Aspectos sociales", 2001, p. 6.

${ }^{96}$ SPLENDIANI, "Cincuenta años de inquisición”, p. 56.
} 
comida, sino colaboraban en la construcción de hospitales y capillas donde el santo lo solicitara, así fuera en zonas de concentración de los africanos y sus descendientes. El fenómeno llega al punto que la intervención económica de la familia Gramajo, portuguesa de origen judío, posibilitó la autorización de la construcción del Colegio Jesuita sobre la muralla de Cartagena y patrocinó la edificación del convento franciscano de San Diego. Así, podemos inferir que las múltiples y constantes ayudas económicas a las órdenes buscaban demostrar que ellos eran indispensables en el puerto y que su conversión al catolicismo era honesta.

Sin embargo, cualquier proceso social donde el dinero y el poder son los protagonistas, manifiesta alianzas y oposiciones cambiantes y este caso no es la excepción. Aquí no solo los portugueses buscaban ganar el favor de Claver pues la amenaza de levantamientos tenía también aterrorizada tanto españoles como a portugueses que se veía en la obligación de invertir en la labor de evangelización. De esa manera, el Proceso muestra que también los sectores españoles dieron grandes sumas de dinero, mientras sus mujeres regalaban ropa o comida para esa causa. La lucha parecía resumirse en quien tenía el favor de la persona mas admirada del puerto. La lista de personas que acompañaron al santo en su deceso e invirtieron su funeral, por demás el más pomposo del periodo, exhibe que Claver fue capaz de unir a los dos sectores europeos en pugna. ${ }^{97}$

\section{Conclusión}

Lo más interesante del Proceso es la elocuencia para delinear dos sectores sociales diametralmente opuestos habitantes de Cartagena: la elite jesuita y los africanos. En ese sentido estamos frente a un documento capacitado para exhibir el choque cultural e ideológico ocurrido en el puerto durante el siglo XVII. En cuanto a los jesuitas, vimos la mentalidad que subyacía a la devoción cristiana de Claver y cómo esta movió sus acciones evangelizadoras hacia los africanos. Con respecto a estos últimos, la fuente señala con detalle las prácticas, creencias y los nombres de los africanos, siendo rica para futuras investigaciones sobre la participación de los representantes de las culturas de África Central y Occidental en el puerto.

${ }^{97}$ ARISTIZABAL, "Proceso de beatificación", p. 434 - 446 y p. 447 - 481. 
Además el Proceso revela que Pedro Claver fue un puente fundamental entre los europeos en el puerto, pues su intención de adoctrinar a los africanos consiguió que los sectores en pugna se aliaran bajo un objetivo común. Sin embargo, su aportación fue limitada con respecto a los africanos quienes continuaron luchando por el mantenimiento sus identidades.

Por último, esta fuente evidencia las formas de exclusión hacia los africanos durante ese periodo en Cartagena. En particular el prejuicio de juzgar que los africanos no podrían razonar y por tanto no deberían recibir instrucción letrada alguna, el enunciar su univoca vocación de servir, así como su mal olor y su naturaleza supersticiosa.

\footnotetext{
${ }^{98}$ La clasificación de las regiones a las cuales pertenece cada lengua derivan de CURTIN Philip, The Atlantic Slave Trade a Census, Madison, University of Wisconsin Press, 1969, p. 109; AROCHA Jaime, "La llegada y los trucos de Ananse", Capítulo 1, In Los ombligados de Ananse, Bogotá, Universidad Nacional de Colombia, 2003, p. 32 Publicado también en http://www.lablaa.org/blaavirtual/antropologia/omblig/3.htm\#(1)
} 


\begin{tabular}{|c|c|c|c|c|}
\hline \multicolumn{5}{|c|}{$\begin{array}{c}\text { TABLA }^{98} \\
\text { Los esclavos que aparecen en el Proceso }\end{array}$} \\
\hline Origen & Número & $\begin{array}{l}\text { Porcentaje } \\
\text { mismo origen }\end{array}$ & Intérpretes & $\begin{array}{l}\text { Porcentaje del } \\
\text { total intérpretes }\end{array}$ \\
\hline Balanta & 3 & $3 \%$ & 2 & $7 \%$ \\
\hline Biafra & 3 & $3 \%$ & 3 & $10 \%$ \\
\hline Branes & 4 & $4 \%$ & 3 & $10 \%$ \\
\hline Cocolí & 2 & $2 \%$ & 2 & $7 \%$ \\
\hline Folupo ¿fulo? & 5 & $5 \%$ & 3 & $10 \%$ \\
\hline Nalu & 2 & $2 \%$ & 1 & $3 \%$ \\
\hline Ríos de los & 1 & $1 \%$ & 1 & $3 \%$ \\
\hline Soso & 1 & $1 \%$ & 1 & $3 \%$ \\
\hline Yolofo & 2 & $2 \%$ & 2 & $7 \%$ \\
\hline Zape & 1 & $1 \%$ & 1 & $3 \%$ \\
\hline $\begin{array}{l}\text { Subtotal } \\
\text { África Occidental }\end{array}$ & & $24 \%$ & & $63 \%$ \\
\hline Angolas & 10 & $11 \%$ & 4 & $14 \%$ \\
\hline Congo & 2 & $2 \%$ & 1 & $3 \%$ \\
\hline Monzolo & 1 & $1 \%$ & 1 & $3 \%$ \\
\hline Yarca_yaka? & 1 & $1 \%$ & 1 & $3 \%$ \\
\hline $\begin{array}{l}\text { Subtotal } \\
\text { África Centro-Occidental }\end{array}$ & & $14 \%$ & & $23 \%$ \\
\hline Cabo Verde & 4 & $4 \%$ & & \\
\hline Carabalí (Af. Occ.) & 1 & $1 \%$ & & \\
\hline Mandinga (Af Occ) & 2 & $2 \%$ & & \\
\hline Lape & 1 & $1 \%$ & & \\
\hline Viozo ¿bioko? & 1 & $1 \%$ & & \\
\hline Etnias sin intérpretes & & $9 \%$ & -- & -- \\
\hline Apelidos Europeos & 13 & $14 \%$ & & \\
\hline "criollo" por apellido & 5 & $5 \%$ & & \\
\hline Sin apeliido & 28 & $30 \%$ & 3 & $10 \%$ \\
\hline $\begin{array}{l}\text { Total esclavos referidos en } \\
\text { el Proceso }\end{array}$ & 93 & & 29 & \\
\hline $\begin{array}{l}\text { Porcentaje de esclavos del } \\
\text { total de } 483 \text { testigos }\end{array}$ & $19 \%$ & & $\begin{array}{l}\text { Porcentaje de } \\
\text { intérpretes del total } \\
\text { de } 93 \text { esclavos }\end{array}$ & $31 \%$ \\
\hline
\end{tabular}

